JOURNAL OF PUBLIC HEALTH INOVATION,

VOL. 2 NO. 01, DESEMBER 2021

DOI: $10.34305 /$ JPHI.V2I1.389
Ciptaan disebarluaskan di bawah Lisensi Creative Commons AtribusiNonKomersial-BerbagiSerupa 4.0 Internasional.

\title{
PAPARAN INSTAGRAM DAN PERAN TEMAN SEBAYA TERHADAP POLA KONSUMSI FAST FOOD PADA REMAJA BERDASARKAN WILAYAH SEKOLAH PERKOTAAN DAN PEDESAAN
}

\author{
Noviyanti Dewi, Icca Stella Amalia, Fitri Kurnia Rahim \\ STIKes Kuningan \\ fikura.zone@gmail.com
}

\begin{abstract}
Abstrak
Pola konsumsi fast food merupakan salah satu faktor penyebab masalah obesitas pada remaja yang semakin meningkat. Pola konsumsi fast food pada remaja dapat dipengaruhi oleh beberapa faktor seperti pengaruh media sosial dan teman sebaya. Tujuan penelitian ini adalah untuk mengetahui pengaruh paparan Instagram dan peran teman sebaya dalam pola konsumsi fast food pada remaja berdasarkan wilayah sekolah perkotaan dan pedesaan di Kabupaten Kuningan Tahun 2018.

Penelitian ini adalah penelitian kuantitatif dengan rancangan cross sectional. Sampel penelitian sebanyak 89 orang siswa kelas XI yang berasal dari wilayah sekolah perkotaan (SMAN 2 Kuningan) dan 88 orang siswa kelas XI dari wilayah sekolah pedesaan (SMAN 1 Kadugede), diambil dengan menggunakan metode proportionate stratified random sampling. Instrumen penelitian yang digunakan adalah kuesioner. Pengumpulan data dilakukan dengan pengisian kuesioner oleh responden. Analisis data dilakukan dengan uji Chi-Square.

Hasil penelitian menunjukkan bahwa pola konsumsi fast food pada remaja di wilayah sekolah pedesaan $(23,9 \%)$ lebih tinggi dibandingkan wilayah sekolah perkotaan $(23,6 \%)$. Remaja yang sering mengkonsumsi fast food karena paparan Instagram di wilayah sekolah perkotaan $(85,7 \%)$ lebih tinggi dibandingan wilayah sekolah pedesaan $(61,9 \%)$, sedangkan remaja yang sering mengkonsumsi fast food karena peran teman sebaya di wilayah sekolah perkotaan $(52,4 \%)$ sama dengan wilayah sekolah pedesaan $(52,4 \%)$. Berdasarkan hasil penelitian diketahui bahwa paparan Instagram mempunyai keterkaitan terhadap pola konsumsi fast food pada remaja, baik di wilayah sekolah perkotaan $(p=0,002)$ maupun pedesaan $(p=0,008)$, sedangkan peran teman sebaya tidak mempunyai keterkaitan terhadap pola konsumsi fast food pada remaja, baik di wilayah sekolah perkotaan $(p=0,586)$ maupun pedesaan $(p=0,08)$.
\end{abstract}


JOURNAL OF PUBLIC HEALTH INOVATION, VOL. 2 NO. 01, DESEMBER 2021

DOI: $\underline{10.34305 / J P H I . V 2 I 1.389}$
Ciptaan disebarluaskan di bawah Lisensi Creative Commons AtribusiNonKomersial-BerbagiSerupa 4.0 Internasional.

Ada pengaruh signifikan paparan Instagram terhadap pola konsumsi fast food pada remaja berdasarkan wilayah sekolah perkotaan dan pedesaan di Kabupaten Kuningan. Diperlukan edukasi/penyuluhan antar teman sebaya yang berkaitan dengan penggunaan Instagram untuk hal-hal yang berdampak positif bagi kesehatan pada remaja.

Kata kunci: Instagram, Teman Sebaya, Fast Food, Remaja, Sekolah

\section{Pendahuluan}

Kegemukan dan obesitas didefinisikan sebagai akumulasi lemak abnormal atau berlebihan yang dapat mengganggu kesehatan. Kegemukan dan obesitas menjadi salah satu penyebab kematian pada sebagian besar penduduk yang tinggal di berbagai negara di mana lebih dari 340 juta anak- anak dan remaja berusia 5-19 tahun mengalami kegemukan atau obesitas pada tahun 2016. Prevalensi kegemukan dan obesitas pada anak-anak dan remaja berusia 5-19 tahun meningkat drastis dari 4\% pada tahun 1975 menjadi 18\% pada tahun 2016 (WHO., 2018).

Menurut Riset Kesehatan Dasar tahun 2013, prevalensi kegemukan dan obesitas pada remaja usia 13-15 tahun di Indonesia sebesar $10,8 \%$, sedangkan pada remaja usia 16-18 tahun sebesar 7,3\% (Kementerian Kesehatan RI., 2013). Di Jawa Barat, prevalensi kegemukan dan obesitas pada remaja usia 13-15 tahun sebesar 9,7\%, sedangkan pada remaja usia 16-18 tahun sebesar 7,6\%. Terdapat 12 Kabupaten/Kota yang memiliki prevalensi kegemukan dan obesitas di atas angka prevalensi Jawa Barat, salah satunya adalah Kabupaten Kuningan a(Dinas Kesehatan Provinsi Jawa Barat., 2017). Prevalensi obesitas berdasarkan jenis kelamin di Kabupaten Kuningan adalah sebesar 8,94, di mana prevalensi obesitas pada perempuan lebih tinggi daripada laki-laki (Dinas Kesehatan Provinsi Jawa Barat., 2017).

Kegemukan dan obesitas pada remaja dapat disebabkan oleh beberapa faktor, salah satunya adalah frekuensi konsumsi fast food yang sering. Hal ini dikarenakan jenis makanan tersebut mengandung energi, gula dan lemak yang tinggi namun rendah serat (Kurdanti et al., 2015). Selain itu, perilaku remaja yang memiliki pengetahuan kurang terkait fast food juga berhubungan dengan kejadian dismenorhoe (Soviyati \& Nurjannah, 2019). Konsumsi fast food pada remaja juga dapat dipengaruhi oleh paparan iklan, 
JOURNAL OF PUBLIC HEALTH INOVATION, VOL. 2 NO. 01, DESEMBER 2021

DOI: $\underline{10.34305 / \text { JPHI.V2I } 1.389}$

pengaruh media, terjadinya urbanisasi dan teman sebaya (Nomate et al., 2017); (Vaida, 2013). Terdapat penelitian yang menunjukkan bahwa media digital dapat memberikan risiko terhadap kesehatan remaja, baik positif maupun negatif. Salah satu risiko negatif yang dapat ditimbulkan akibat penggunaan media digital adalah meningkatkan risiko obesitas pada remaja (Chassiakos et al., 2016). Penelitian lainnya juga menunjukkan bahwa dukungan teman sebaya yang tinggi untuk mengkonsumsi makanan yang tidak sehat berhubungan dengan asupan makanan yang tidak sehat (Fitzgerald et al., 2013) dan teman sebaya memiliki pengaruh terhadap konsumsi fast food di kalangan remaja yang tergabung dalam jaringan sekolah pertemanan yang sama (Fortin \& Yazbeck, 2015).

Remaja mudah dipengaruhi oleh lingkungan di mana mereka tinggal dan bergaul di tengah-tengah masyarakat, termasuk diantaranya adalah lingkungan sekolah. Lingkungan sekolah baik perkotaan maupun pedesaan dapat mempengaruhi perilaku remaja (Story et al., 2002). Perilaku remaja tersebut salah satunya dapat berdampak pada gaya hidup remaja masa kini, tidak terkecuali dengan pola konsumsi fast food. SMAN 2
Ciptaan disebarluaskan di bawah Lisensi Creative Commons AtribusiNonKomersial-BerbagiSerupa 4.0 Internasional.

Kuningan merupakan salah satu sekolah yang berada di wilayah perkotaan (pusat kota/kabupaten), sedangkan SMAN 1 Kadugede merupakan salah satu sekolah yang berada di wilayah pedesaan di Kabupaten Kuningan. Penelitian ini bertujuan untuk mengetahui pengaruh paparan Instagram dan peran teman sebaya dalam pola konsumsi fast food pada remaja berdasarkan wilayah sekolah perkotaan dan pedesaan di Kabupaten Kuningan Tahun 2018.

\section{Metode}

Penelitian ini dilaksanakan pada bulan Agustus 2018 di SMAN 2 Kuningan yang mewakili wilayah sekolah perkotaan dan SMAN 1 Kadugede yang mewakili wilayah sekolah pedesaan di Kabupaten Kuningan. Penelitian ini merupakan penelitian kuantitatif dengan rancangan cross sectional. Besar sampel dalam penelitian ini dihitung dengan menggunakan rumus proporsi sebesar $25 \%$ dari jumlah seluruh populasi yang diteliti. Berdasarkan rumus tersebut diperoleh 89 sampel yang berasal dari wilayah sekolah perkotaan dan 88 sampel dari wilayah sekolah pedesaan. Pengambilan sampel penelitian menggunakan metode proportionate stratified random sampling 
JOURNAL OF PUBLIC HEALTH INOVATION, VOL. 2 NO. 01, DESEMBER 2021

DOI: $\underline{10.34305 / \text { JPHI.V2I } 1.389}$

dengan kriteria inklusi yaitu remaja merupakan siswa kelas XI di SMAN 2 Kuningan maupun SMAN 1 Kadugede Kabupaten Kuningan tahun 2018 dan bersedia menjadi responden.

Variabel independen dalam penelitian ini adalah paparan Instagram dan peran teman sebaya. Variabel dependen dalam penelitian ini adalah pola konsumsi fast food pada remaja. Data yang dikumpulkan meliputi karakteristik responden (jenis kelamin, usia, pendidikan orang tua, pekerjaan orang tua, status anak, uang saku, kepemilikan aplikasi Instagram dan kepemilikan akun Instagram ), pola konsumsi fast food responden, serta paparan Instagram dan peran teman sebaya dalam pola konsumsi fast food responden yang diperoleh melalui pengisian kuesioner. Adapun kuesioner tersebut telah diuji validitasnya terlebih dahulu dengan nilai $r$ tabel $=0,374$. Analisis data dilakukan dengan menggunakan software statistik. Penelitian ini menggunakan analisis univariat dan bivariat. Adapun uji statistik yang digunakan dalam penelitian ini adalah uji Chi-Square dengan tingkat signifikansi 5\% $(\alpha=0,05)$.
Ciptaan disebarluaskan di bawah Lisensi Creative Commons AtribusiNonKomersial-BerbagiSerupa 4.0 Internasional.

\section{Hasil}

Pada tabel 1. dapat diketahui bahwa sebagian besar responden di wilayah sekolah perkotaan berjenis kelaminperempuan $(69,7 \%)$, berusia $\leq 16$ tahun $(92,1 \%)$, mempunyai orang tua dengan pendidikan terakhir Akademi/Perguruan Tinggi (PT) (62,9\%) dan bekerja sebagai PNS (39,3\%), berstatus sebagai anak ke 1-2 (86,5\%), mempunyai uang saku sebesar $\leq \mathrm{Rp} 20.000$ per hari (57,3\%), memiliki aplikasi Instagram pada gadget milik sendiri $(97,8 \%)$ dan memiliki akun Instagram sendiri (97,8\%).

Sementara itu, sebagian besar responden di wilayah sekolah pedesaan berjenis kelamin perempuan $(72,7 \%)$, berusia $\leq 16$ tahun $(89,8 \%)$, mempunyai orang tua dengan pendidikan terakhir SMA $(42,0 \%)$ dan bekerja sebagai wiraswasta $(39,8 \%)$, berstatus sebagai anak ke $1-2$ (73,9\%), mempunyai uang saku sebesar $\leq \mathrm{Rp} 20.000$ per hari $(87,5 \%)$, memiliki aplikasi Instagram pada gadget milik sendiri $(90,9 \%)$ dan memiliki akun Instagram sendiri $\quad(92,0 \%)$. 
JOURNAL OF PUBLIC HEALTH INOVATION, VOL. 2 NO. 01, DESEMBER 2021

DOI: $10.34305 /$ JPHI.V2I1.389
Ciptaan disebarluaskan di bawah Lisensi Creative Commons AtribusiNonKomersial-BerbagiSerupa 4.0 Internasional.

Tabel 1. Gambaran Karakteristik Remaja Berdasarkan Wilayah Sekolah Perkotaan Dan Pedesaan Di Kabupaten Kuningan Tahun 2018

\begin{tabular}{|c|c|c|c|c|}
\hline \multirow{3}{*}{$\begin{array}{l}\text { Karakteristik Remaja } \\
\text { Responden }\end{array}$} & \multicolumn{4}{|c|}{ Wilayah Sekolah } \\
\hline & \multicolumn{2}{|c|}{ Perkotaan } & \multicolumn{2}{|c|}{ Pedesaan } \\
\hline & $\mathbf{N}$ & $\%$ & $\mathbf{N}$ & $\%$ \\
\hline \multicolumn{5}{|l|}{ Jenis Kelamin } \\
\hline Laki-laki & 27 & 30,3 & 24 & 27,3 \\
\hline Perempuan & 62 & 69,7 & 64 & 72,7 \\
\hline \multicolumn{5}{|l|}{ Usia } \\
\hline$\leq 16$ tahun & 82 & 92,1 & 79 & 89,8 \\
\hline$>16$ tahun & 7 & 7,9 & 9 & 10,2 \\
\hline \multicolumn{5}{|l|}{ Pendidikan Terakhir Orang Tua } \\
\hline Tidak Tamat SD & 0 & 0 & 0 & 0 \\
\hline $\mathrm{SD}$ & 3 & 3,4 & 16 & 18,2 \\
\hline SMP & 5 & 5,6 & 13 & 14,8 \\
\hline SMA & 25 & 28,1 & 37 & 42 \\
\hline Akademi/Perguruan Tinggi (PT) & 56 & 62,9 & 22 & 25 \\
\hline \multicolumn{5}{|l|}{ Pekerjaan Orang Tua } \\
\hline Petani & 1 & 1,1 & 3 & 3,4 \\
\hline PNS & 35 & 39,3 & 19 & 21,6 \\
\hline Pegawai Swasta & 10 & 11,2 & 7 & 8 \\
\hline Wiraswasta & 27 & 30,3 & 35 & 39,8 \\
\hline Lainnya & 16 & 18 & 24 & 27,3 \\
\hline \multicolumn{5}{|l|}{ Status Anak (Anak ke-) } \\
\hline $1-2$ & 77 & 86,5 & 65 & 73,9 \\
\hline$>2$ & 12 & 13,5 & 23 & 26,1 \\
\hline \multicolumn{5}{|c|}{ Kepemilikan aplikasi Instagram pada gadget yang dimiliki } \\
\hline Ya & 87 & 97,8 & 80 & 90,9 \\
\hline Tidak & 2 & 2,2 & 8 & 9,1 \\
\hline \multicolumn{5}{|l|}{ Kepemilikan akun Instagram } \\
\hline $\mathrm{Ya}$ & 87 & 97,8 & 81 & 92 \\
\hline Tidak & 2 & 2,2 & 7 & 8 \\
\hline Jumlah & 89 & 100 & 88 & 100 \\
\hline
\end{tabular}

Pada tabel 2. menunjukkan bahwa sebagian besar responden tidak sering mengkonsumsi fast food, baik di wilayah sekolah perkotaan (76,4\%) maupun pedesaan $(76,1 \%)$, sebagian besar responden di wilayah sekolah perkotaan terpapar oleh Instagram dalam pola konsumsi fast food (56,2\%), sedangkan sebagian besar responden di wilayah sekolah pedesaan tidak terpapar oleh Instagram dalam pola konsumsi fast food $(62,5 \%)$, serta sebagian besar responden 
JOURNAL OF PUBLIC HEALTH INOVATION, VOL. 2 NO. 01, DESEMBER 2021

DOI: $10.34305 /$ JPHI.V2I1.389

menilai teman sebaya tidak berperan dalam pola konsumsi fast food, baik di wilayah
Ciptaan disebarluaskan di bawah Lisensi Creative Commons AtribusiNonKomersial-BerbagiSerupa 4.0 Internasional.

\section{(CC}

sekolah perkotaan $(52,8 \%)$ maupun

pedesaan

$(63,6 \%)$.

Tabel 2. Gambaran Pola Konsumsi, Paparan Instagram dan Peran Teman Sebaya dalam Pola Konsumsi Fast food pada Remaja Berdasarkan Wilayah Sekolah Perkotaan dan Pedesaan di Kabupaten Kuningan Tahun 2018

\begin{tabular}{|c|c|c|c|c|}
\hline \multirow{3}{*}{ Variabel } & \multicolumn{4}{|c|}{ Wilayah Sekolah } \\
\hline & \multicolumn{2}{|c|}{ Perkotaan } & \multicolumn{2}{|c|}{ Pedesaan } \\
\hline & $\mathbf{N}$ & $\%$ & $\mathbf{N}$ & $\%$ \\
\hline \multicolumn{5}{|l|}{ Pola Konsumsi Fast Food } \\
\hline Sering & 21 & 23,6 & 21 & 23,9 \\
\hline Tidak Sering & 68 & 76,4 & 67 & 76,1 \\
\hline \multicolumn{5}{|c|}{ Paparan Instagram Dalam Pola Konsumsi Fast Food } \\
\hline Terpapar & 50 & 56,2 & 33 & 37,5 \\
\hline Tidak Terpapar & 39 & 43,8 & 55 & 62,5 \\
\hline \multicolumn{5}{|c|}{ Peran Teman Sebaya Dalam Pola Konsumsi Fast Food } \\
\hline Berperan & 42 & 47,2 & 32 & 36,4 \\
\hline Tidak Berperan & 47 & 52,8 & 56 & 63,6 \\
\hline Jumlah & 89 & 100 & 88 & 100 \\
\hline
\end{tabular}

Pada tabel 3. dapat diketahui bahwa sebagian besar responden di wilayah sekolah perkotaan yang tidak sering mengkonsumsi fast food karena tidak terpapar oleh Instagram yaitu sebanyak 36 orang $(52,9 \%)$ dan sebagian besar yang sering mengkonsumsi fast food karena terpapar oleh Instagram yaitu 18 orang $(85,7 \%)$, sedangkan sebagian besar responden di wilayah sekolah pedesaan yang tidak sering mengkonsumsi fast food karena tidak terpapar oleh Instagram yaitu sebanyak 47 orang $(70,1 \%)$ dan sebagian besar yang sering mengkonsumsi fast food karena terpapar oleh Instagram yaitu 13 orang (61,9\%). Berdasarkan hasil uji ChiSquare diperoleh $p$ Value atau nilai $p=0,002 \quad(\mathrm{p}<0,05)$ untuk wilayah sekolah perkotaan dan nilai $p=0,008 \quad(\mathrm{p}<0,05)$ untuk wilayah sekolah pedesaan, artinya ada pengaruh signifikan paparan Instagram terhadap pola konsumsi fast food pada remaja berdasarkan wilayah sekolah perkotaan dan pedesaan.

Berdasarkan tabel tersebut juga dapat diketahui bahwa sebagian besar responden di wilayah sekolah perkotaan yang tidak sering mengkonsumsi fast food karena tidak ada peran teman sebaya yaitu sebanyak 37 orang $(54,4 \%)$ dan sebagian 
JOURNAL OF PUBLIC HEALTH INOVATION, VOL. 2 NO. 01, DESEMBER 2021

DOI: $10.34305 /$ JPHI.V2I1.389

besar yang sering mengkonsumsi fast food karena peran teman sebaya yaitu 11 orang $(52,4 \%)$, sedangkan sebagian besar responden di wilayah sekolah pedesaan yang tidak sering mengkonsumsi fast food karena tidak ada peran teman sebaya yaitu sebanyak 46 orang $(68,7 \%)$ dan sebagian besar yang sering mengkonsumsi fast food karena peran teman sebaya yaitu 11 orang
Ciptaan disebarluaskan di bawah Lisensi Creative Commons AtribusiNonKomersial-BerbagiSerupa 4.0 Internasional.

(52,4\%). Berdasarkan hasil uji Chi-Square diperoleh $p$ Value atau nilai $p=0,586$ ( $>0,05)$ untuk wilayah sekolah perkotaan dan nilai $p=0,08(\mathrm{p}>0,05)$ untuk wilayah sekolah pedesaan, artinya tidak ada pengaruh signifikan peran teman sebaya terhadap pola konsumsi fast food pada remaja di wilayah sekolah perkotaan dan pedesaan.

Tabel 3. Pengaruh Paparan Instagram dan Peran Teman Sebaya dalam Pola Konsumsi Fast food pada Remaja Berdasarkan Wilayah Sekolah Perkotaan dan Pedesaan di Kabupaten Kuningan Tahun 2018

\begin{tabular}{|c|c|c|c|c|c|c|c|c|c|c|}
\hline \multirow{4}{*}{ Variabel } & \multicolumn{9}{|c|}{ Pola Konsumsi Fast food Pada Remaja } & \multirow{4}{*}{ P Value } \\
\hline & \multicolumn{4}{|c|}{ Wilayah Sekolah Perkotaan } & \multicolumn{5}{|c|}{ Wilayah Sekolah Pedesaan } & \\
\hline & \multicolumn{2}{|c|}{ Tidak Sering } & \multicolumn{2}{|c|}{ Sering } & \multirow{2}{*}{$\begin{array}{c}P \\
\text { Value }\end{array}$} & \multicolumn{2}{|c|}{ Tidak Sering } & \multicolumn{2}{|c|}{ Sering } & \\
\hline & $\mathbf{N}$ & $\%$ & $\mathbf{N}$ & $\%$ & & $\mathbf{N}$ & $\%$ & $\mathbf{N}$ & $\%$ & \\
\hline \multicolumn{11}{|c|}{ Paparan Instagram } \\
\hline $\begin{array}{l}\text { Tidak } \\
\text { Terpapar }\end{array}$ & 36 & 52,9 & 3 & 14,3 & \multirow{2}{*}{0,002} & 47 & 70,1 & 8 & 38,1 & \multirow{2}{*}{0,008} \\
\hline Terpapar & 32 & 47,1 & 18 & 85,7 & & 20 & 29,9 & 13 & 61,9 & \\
\hline \multicolumn{11}{|c|}{ Peran Teman Sebaya } \\
\hline $\begin{array}{l}\text { Tidak } \\
\text { Berperan }\end{array}$ & 37 & 54,4 & 10 & 47,6 & \multirow[t]{2}{*}{0,586} & 46 & 68,7 & 10 & 47,6 & \multirow[t]{2}{*}{0,08} \\
\hline Berperan & 31 & 45,6 & 11 & 52,4 & & 21 & 31,3 & 11 & 52,4 & \\
\hline
\end{tabular}

\section{Pembahasan}

Karakteristik Remaja Berdasarkan Wilayah Sekolah Perkotaan dan Pedesaan

Berdasarkan hasil penelitian diperoleh hasil bahwa sebagian besar responden di wilayah sekolah perkotaan dan pedesaan berjenis kelamin perempuan, mempunyai uang saku $\leq$ Rp20.000 per hari dan memiliki akun Instagram sendiri.
Menurut hasil penelitian yang dilakukan oleh Pew Research Centre menunjukkan bahwa perempuan (76\%) lebih mendominasi dalam penggunaan media sosial dibandingkan dengan laki-laki (72\%) (Lubis, 2015). Besarnya uang saku remaja berkaitan erat dengan pemilihan jenis makanan yang dikonsumsi, di mana remaja yang mendapatkan uang saku lebih dari $\mathrm{Rp}$ 
JOURNAL OF PUBLIC HEALTH INOVATION, VOL. 2 NO. 01, DESEMBER 2021

DOI: $10.34305 /$ JPHI.V2I1.389

25.000 memiliki kesempatan yang lebih besar untuk sering mengkonsumsi makanan- makanan modern seperti fast food daripada remaja yang uang sakunya kurang dari $\mathrm{Rp} 25.000$ untuk membeli berbagai makanan yang tidak sehat dengan harapan akan diterima di kalangan teman sebayanya (Adam, D., 2016). Hasil penelitian juga menunjukkan bahwa sebanyak 68\% subjek pengguna media sosial Instagram membuka akun miliknya setiap hari (Sifa \& Sawitri, 2018).

Pola Konsumsi Fast food pada Remaja Berdasarkan Wilayah Sekolah Perkotaan dan Pedesaan

$$
\text { Berdasarkan hasil penelitian }
$$
diperoleh hasil bahwa sebagian besar responden di wilayah sekolah perkotaan dan pedesaan mempunyai pola konsumsi fast food $\leq 3$ kali perminggu atau tidak sering mengkonsumsi fast food. Hal ini disebabkan oleh rendahnya uang saku remaja sebagaimana hasil penelitian ini yang menunjukkan bahwa sebagian besar remaja, baik di wilayah sekolah perkotaan maupun pedesaan mempunyai uang saku $\leq \mathrm{Rp} 20.000$ per hari. Hasil penelitian lain menyatakan bahwa remaja dengan uang saku $<\mathrm{Rp} 25.000$ mempunyai risiko lebih
Ciptaan disebarluaskan di bawah Lisensi Creative Commons AtribusiNonKomersial-BerbagiSerupa 4.0 Internasional.

rendah untuk mengkonsumsi makanan modern seperti fast food (Adam, D., 2016).

Terdapat dua faktor yang menyebabkan remaja mempunyai pola makan atau konsumsi fast food, yaitu faktor internal dan eksternal. Faktor internal merupakan faktor yang berasal dari dalam diri remaja yang dapat berupa sifat kebiasaan, sedangkan faktor eksternal merupakan faktor yang berasal dari luar diri remaja yang dapat berupa ketersediaan pangan dan status sosial ekonomi yang mempengaruhi tingkat daya beli (Istiany, 2013). Individu yang memiliki uang saku lebih cenderung memiliki daya beli yang tinggi sehingga mempunyai resiko untuk mengkonsumsi fast food (Kusgandari, 2018).

Paparan Instagram dalam Pola Konsumsi Fast food pada Remaja Berdasarkan Wilayah Sekolah Perkotaan dan Pedesaan

Berdasarkan hasil penelitian diperoleh hasil bahwa sebagian besar responden di wilayah sekolah perkotaan terpapar oleh Instagram dalam pola konsumsi fast food, sedangkan sebagian besar responden di wilayah sekolah pedesaan tidak terpapar oleh Instagram dalam pola konsumsi fast food. Meskipun terdapat hasil penelitian yang menunjukkan 
JOURNAL OF PUBLIC HEALTH INOVATION, VOL. 2 NO. 01, DESEMBER 2021

DOI: $\underline{10.34305 / \text { JPHI.V2I } 1.389}$

bahwa remaja di perkotaan dan perdesaan adalah pengguna berat media social (Ramadhan \& Giyarsih, 2017), tetapi remaja yang berada di wilayah sekolah perkotaan lebih sering terpapar oleh Instagram dalam pola konsumsi fast food.

Hasil penelitian yang menunjukkan bahwa sebagian besar siswa di wilayah sekolah perkotaan menyatakan setuju menggunakan Instagram untuk memperoleh informasi tentang fast food $(42,7 \%)$ daripada siswa di wilayah sekolah pedesaan $(30,6 \%)$. Hal ini juga diperkuat dengan terdapatnya sebagian besar remaja di wilayah sekolah perkotaan $(55,1 \%)$ yang menyatakan lebih sering menggunakan Instagram dibandingkan dengan media sosial lainnya daripada remaja di wilayah sekolah pedesaan (43,2\%). Makanan modern seperti fast food yang diiklankan melalui media internet memiliki daya pikat tersendiri bagi sebagian golongan remaja (Halid \& Sudargo, 2016) seperti salah satunya ditampilkan melalui Instagram sehingga remaja tertarik untuk mengkonsumsinya.

Peran Teman Sebaya dalam Pola Konsumsi Fast food pada Remaja Berdasarkan Wilayah Sekolah Perkotaan dan Pedesaan
Ciptaan disebarluaskan di bawah Lisensi Creative Commons AtribusiNonKomersial-BerbagiSerupa 4.0 Internasional.

Berdasarkan hasil penelitian diperoleh hasil bahwa sebagian besar responden di wilayah sekolah perkotaan dan pedesaan menilai teman sebaya tidak berperan dalam pola konsumsi fast food. Hasil penelitian menunjukkan bahwa sebagian besar remaja di wilayah sekolah perkotaan $(55,1 \%)$ dan pedesaan $(59,1 \%)$ menyatakan tidak setuju bahwa teman sebaya mempengaruhi pola makan mereka.

Terdapat penelitian yang menyimpulkan bahwa teman sebaya tidak cukup berperan terhadap perilaku makan remaja. Hal tersebut disebabkan sebagian besar remaja masih tinggal bersama orang tua. Dengan demikian, orang tua masih memegang peranan penting dalam membentuk perilaku makan remaja (Rahman et al., 2016).

Pengaruh Paparan Instagram dalam Pola Konsumsi Fast food pada Remaja Berdasarkan Wilayah Sekolah Perkotaan dan Pedesaan

Berdasarkan hasil uji Chi-Square diperoleh nilai $p=0,002$ untuk wilayah sekolah perkotaan dan $p=0,008$ untuk wilayah sekolah pedesaan. Artinya, nilai $p$ lebih kecil dari nilai alpha $(p<\alpha)$ dengan $\alpha=0,05$ sehingga Ho ditolak. Maka, dapat disimpulkan ada pengaruh signifikan 
JOURNAL OF PUBLIC HEALTH INOVATION, VOL. 2 NO. 01, DESEMBER 2021

DOI: $\underline{10.34305 / \text { JPHI.V2I } 1.389}$

paparan Instagram terhadap pola konsumsi fast food pada remaja berdasarkan wilayah sekolah perkotaan dan pedesaan.

Terdapat penelitian yang menyatakan bahwa bisnis makanan cepat saji (fast food) mendapatkan lebih banyak perhatian di media sosial (Mejova et al., 2015) dan remaja merupakan target utama dari periklanan dalam promosi fast food tersebut yang dapat mempengaruhi perilaku pemilihan makanan mereka (Halid \& Sudargo, 2016). Namun, remaja yang berada di wilayah sekolah perkotaan cenderung lebih berisiko untuk mengkonsumsi fast food karena pengaruh paparan Instagram dibandingkan dengan wilayah sekolah pedesaan. Hal ini sesuai dengan hasil penelitian yang menunjukkan bahwa sebagian besar remaja di wilayah sekolah perkotaan $(39,3 \%)$ tertarik untuk mengkonsumsi fast food yang sedang trend di Instagram daripada remaja di wilayah sekolah pedesaan $(21,6 \%)$.

Besarnya risiko remaja untuk mengkonsumsi fast food karena pengaruh paparan Instagram dapat dilihat dari frekuensi penggunaan Instagram . Hasil penelitian ini menunjukkan bahwa frekuensi penggunaan Instagram selama lebih dari 1 jam pada remaja di wilayah sekolah perkotaan (65\%) lebih tinggi
Ciptaan disebarluaskan di bawah Lisensi Creative Commons AtribusiNonKomersial-BerbagiSerupa 4.0 Internasional.

daripada remaja di wilayah sekolah pedesaan (42\%). Hal ini sejalan dengan hasil penelitian lain yang menyatakan bahwa remaja sering mengakses media sosial selama lebih dari 80 menit per hari (Ramadhan \& Giyarsih, 2017)

Pengaruh Peran Teman Sebaya dalam Pola Konsumsi Fast food pada Remaja Berdasarkan Wilayah Sekolah Perkotaan dan Pedesaan

Berdasarkan hasil uji Chi-Square diperoleh nilai $p=0,586$ untuk wilayah sekolah perkotaan dan $p=0,08$ untuk wilayah sekolah pedesaan. Artinya, nilai $p$ lebih besar dari nilai alpha $(p<\alpha)$ dengan $\alpha=0,05$ sehingga Ho gagal ditolak (diterima). Maka, dapat disimpulkan tidak ada pengaruh signifikan peran teman sebaya terhadap pola konsumsi fast food pada remaja berdasarkan wilayah sekolah perkotaan dan pedesaan.

Berdasarkan hasil penelitian, peran teman sebaya dalam pola konsumsi fast food pada remaja yang berada di wilayah sekolah perkotaan maupun pedesaan tidak jauh berbeda. Hal ini ditunjukkan dengan terdapatnya sebagian besar remaja, baik di wilayah sekolah perkotaan $(47,2 \%)$ maupun pedesaan $(55,7 \%)$ menyatakan tidak setuju bahwa mengkonsumsi fast food 
JOURNAL OF PUBLIC HEALTH INOVATION, VOL. 2 NO. 01, DESEMBER 2021

DOI: $\underline{10.34305 / \text { JPHI.V2I } 1.389}$

karena pengaruh/ajakan teman sebaya. Hasil penelitian ini sejalan dengan hasil penelitian lain yang menyimpulkan bahwa tidak ada hubungan antara teman sebaya dan frekuensi konsumsi fast food (Nusa \& Adi, 2013). Hal ini dapat disebabkan rendahnya interaksi antar teman sebaya karena pengaruh teknologi di masa kini, seperti tersedianya akses komunikasi dengan teman sebaya melalui media sosial.

\section{Kesimpulan}

Berdasarkan hasil penelitian ini, maka dapat disimpulkan terdapat pengaruh signifikan paparan Instagram terhadap pola konsumsi fast food pada remaja berdasarkan wilayah sekolah perkotaan dan pedesaan di Kabupaten Kuningan Tahun 2018.

\section{Saran}

Pihak sekolah disarankan dapat bekerja sama dengan instansi kesehatan setempat, seperti puskesmas untuk melakukan pemberdayaan kepada remaja agar dapat melakukan penyuluhan terkait penggunaan media sosial Instagram untuk hal-hal yang berdampak positif bagi kesehatan antar teman sebaya.

\section{Daftar Pustaka}

Ciptaan disebarluaskan di bawah Lisensi Creative Commons AtribusiNonKomersial-BerbagiSerupa 4.0 Internasional.
Adam, D., D. (2016). Faktor Risiko Kejadian Obesitas Pada Remaja Di Sman 1 Kabila Kabupaten Bone Bolango. Community Health, 4(1).

Chassiakos, Y. L. R., Radesky, J., Christakis, D., Moreno, M. A., \& Cross, C. (2016). Children And Adolescents And Digital Media. Pediatrics, 138(5).

Dinas Kesehatan Provinsi Jawa Barat. (2017). Profil Kesehatan Jawa Barat Tahun 2016.

Fitzgerald, A., Heary, C., Kelly, C., Nixon, E., \& Shevlin, M. (2013). SelfEfficacy For Healthy Eating And Peer Support For Unhealthy Eating Are Associated With Adolescents' Food Intake Patterns. Appetite, 63, $48-58$.

Fortin, B., \& Yazbeck, M. (2015). Peer Effects, Fast Food Consumption And Adolescent Weight Gain. Journal Of Health Economics, 42, 125-138.

Halid, M., \& Sudargo, T. (2016). Hubungan Status Sosial Ekonomi Dengan Tingkat Konsumsi Fast Food Pada Remaja. Biota: Biologi Dan Pendidikan Biologi, 9(1), 74-85.

Istiany, A. (2013). Rusilanti. 2013. Gizi Terapan. Pt. Remaja Rosdakarya. Bandung.

Kementerian Kesehatan Ri. (2013). Riset Kesehatan Dasar 2013.

Kurdanti, W., Suryani, I., Syamsiatun, N. H., Siwi, L. P., Adityanti, M. M., Mustikaningsih, D., \& Sholihah, K. I. (2015). Faktor-Faktor Yang 
JOURNAL OF PUBLIC HEALTH INOVATION, VOL. 2 NO. 01, DESEMBER 2021

DOI: $\underline{10.34305 / \text { JPHI.V2I } 1.389}$

Mempengaruhi Kejadian Obesitas Pada Remaja. Jurnal Gizi Klinik Indonesia, 11(4), 179-190.

Kusgandari, G. (2018). Analisis Faktor Yang Mempengaruhi Perilaku Konsumsi Fast Food Pada SiswaSiswi Di Sma Negeri “ $X$ ” Surabaya. Universitas Airlangga.

Lubis, E. E. (2015). Potret Media Sosial Dan Perempuan. Jurnal Parallela, 1(2), 97-106.

Mejova, Y., Haddadi, H., Noulas, A., \& Weber, I. (2015). \# Foodporn: Obesity Patterns In Culinary Interactions. Proceedings Of The 5th International Conference On Digital Health 2015, 51-58.

Nomate, E. S., Nur, M. L., \& Toy, S. M. (2017). Hubungan Teman Sebaya, Citra Tubuh Dan Pola Konsumsi Dengan Status Gizi Remaja Putri. Unnes Journal Of Public Health, 6(3), 141-147.

Nusa, A. F. A., \& Adi, A. C. (2013). Hubungan Faktor Perilaku, Frekuensi Konsumsi Fast Food, Diet Dan Genetik Dengan Tingkat Kelebihan Berat Badan. Media Gizi Indonesia, 9(1), 20-27.

Rahman, N., Dewi, N. U., \& Armawaty, F. (2016). Faktor-Faktor Yang Berhubungan Dengan Perilaku Makan Pada Remaja Sma Negeri 1 Palu. Preventif: Jurnal Kesehatan
Ciptaan disebarluaskan di bawah Lisensi Creative Commons AtribusiNonKomersial-BerbagiSerupa 4.0 Internasional.

Masyarakat, 7(1), 10.

Ramadhan, H. W., \& Giyarsih, S. R. (2017). Hubungan Media Sosial Dengan Persepsi Remaja Tentang Kesehatan Reproduksi Menurut Wilayah Perkotaan Dan Perdesaan Di Yogyakarta. Jurnal Bumi Indonesia, 6(3).

Sifa, I. A. M., \& Sawitri, D. R. (2018). Hubungan Regulasi Diri Dengan Adiksi Media Sosial Instagram Pada Siswa Smk Jayawisata Semarang. Undip.

Soviyati, E., \& Nurjannah, S. (2019). Hubungan Pengetahuan Makanan Cepat Saji (Fast Food) Dengan Kejadian Dismenorhoe Pada Siswi Kelas Vii Di Smpn 2 Jalaksana Kecamatan Jalaksana Kabupaten Kuningan Tahun 2018. Jurnal Ilmu Kesehatan Bhakti Husada: Health Sciences Journal, 10(1), 28-33.

Story, M., Neumark-Sztainer, D., \& French, S. (2002). Individual And Environmental Influences On Adolescent Eating Behaviors. Journal of The American Dietetic Association, 102(3), S40-S51.

Vaida, N. (2013). Prevalence Of Fast Food Intake Among Urban Adolescent Students. The International Journal Of Engineering And Science, 2(1), 353-359.

Who. (2018). Obesity And Overweight. 